\title{
Adenovirus vectors differentially modulate proliferation of pituitary lactotrophs in primary culture in a mitogen and infection time- dependent manner
}

\author{
Zhenhua Wang $^{1,2}$, Tetsuo Mitsui ${ }^{1}$, Maho Ishida ${ }^{1}$ and Jun Arita ${ }^{1}$ \\ ${ }^{1}$ Department of Physiology, Interdisciplinary Graduate School of Medicine and Engineering, University of Yamanashi, Yamanashi 409-3898, Japan \\ ${ }^{2}$ Department of Physiology, College of Basic Medicine, China Medical University, Shenyang 110001, People's Republic of China \\ (Correspondence should be addressed to J Arita; Email: jarita@yamanashi.ac.jp)
}

\begin{abstract}
Adenoviruses are powerful, widely utilized vectors for gene transfer. Limitations to their application, however, have not been well described. We used rat pituitary lactotrophs in primary culture as a model for studying how adenovirus vector infection modulates mitogen-induced proliferation and the activities of mitogen signaling pathways. Infection with adenovirus vectors expressing $\beta$-galactosidase ( $\beta$ gal) raised basal proliferative levels and blocked fetal bovine serum (FBS)-induced proliferation of lactotrophs, but did not influence the changes in proliferation induced by forskolin, IGF-I, and bromocriptine. The $\beta \mathrm{gal}-$ expressing adenoviruses did not alter the inhibitory action of $17 \beta$-estradiol $\left(\mathrm{E}_{2}\right)$ in the presence of IGF-I; however, they blocked the stimulatory action of $\mathrm{E}_{2}$ in the presence of dextrancoated charcoal-striped serum or forskolin. An adenovirus expressing no protein failed to block FBS-induced proliferation, but was effective in modulating basal proliferative levels and the stimulatory actions of $\mathrm{E}_{2}$. The increased basal proliferative level
\end{abstract}

and the blockade of FBS-induced proliferation were transient, and lost 5 days after infection while the blockade of the stimulatory action of $E_{2}$ in the presence of forskolin persisted. Adenovirus infection raised basal protein levels of the phosphorylated forms of cAMP response element-binding protein (pCREB) and ERK1/2 and increased the proportion of pCREB-immunoreactive lactotrophs. Adenoviruses also altered estrogen-induced responses in mRNA expression of several estrogen-responsive genes in a gene-specific manner. The results demonstrate that an adenovirus vector differentially interferes with lactotroph proliferation in response to various mitogens. Our results suggest that the effects of the adenovirus that are independent of the genes transferred must be considered when performing adenoviral gene transfer in the primary cultures of normal cells.

Journal of Endocrinology (2008) 198, 209-217

\section{Introduction}

In recent years virus-mediated gene transfer has been widely applied in primary cultures of normal cells, and to cells in vivo in which conventional methods of gene transfer are unsuccessful. Together with lentiviruses and adeno-associated viruses, replication-defective adenoviruses that are genetically modified by deletions within the viral genome to allow insertion of foreign genes, are the most commonly used viral vectors (Yeh \& Perricaudet 1997, Seth 2000). Adenoviruses have a high efficiency of gene transfer, are able to transfer in nonproliferating cells, resulting in sustained high expression of transferred genes, and are easily prepared with high viral titers. Therefore, in addition to experimental studies, adenovirus vectors have been used for gene therapy in human diseases (Crystal et al. 1994). However, adenovirus-mediated gene transfer has disadvantages too. The first generation of adenovirus vectors induces immunological responses when infected in vivo (Dai et al. 1995, Yang et al. 1995, Lieber et al.

1997b). This has only been partially resolved in improved adenovirus vectors (Lieber et al. 1997a, Chirmule et al. 1998).

Adenovirus infection and gene transfer in vitro also interfere with specific cell functions in cultured cells. Adenovirus vectors enhance cell survival and inhibit apoptosis in endothelial (Ramalingam et al. 1999, Zhang et al. 2004) and lung epithelial cells in culture (Flaherty et al. 2004). However, the effect of adenovirus vector infection is poorly understood in endocrine cells. Castro et al. (1997) reported that infection of the primary cultures of anterior pituitary cells with an adenovirus expressing $\beta$-galactosidase ( $\beta$ gal), at multiplicities of infection (MOIs) up to 5 , did not affect hormone secretion. However, infection at a MOI of 20 increased basal secretion and conversely decreased secretagogue-stimulated secretion of adrenocorticotropin $(\mathrm{ACTH})$ and luteinizing hormone. Adenoviruses expressing green fluorescent protein and $\beta$ gal also increased the basal secretion of adrenocortical steroids such as cortisol, 17-hydroxyprogesterone, and 11-deoxycortisol and decreased their ACTH-stimulated secretion in bovine 
adrenocortical cells in the primary culture (Alesci et al. 2002). In association with the increase in basal hormone secretion, an increase in $\left[{ }^{3} \mathrm{H}\right]$ thymidine uptake is observed in adenovirusinfected cells, suggesting that the increased basal secretion by adenoviruses is caused by an increased cell number.

Understanding how adenovirus vectors interfere with specific cell functions and intracellular signaling will assist with designing experiments that use these vectors appropriately. Additionally, knowing the limitations of adenovirus vectors will aid with correctly interpreting experimental data. Therefore, in this study, we used the rat pituitary lactotroph in the primary culture as a model for studying how adenovirus vector infection modulates cell proliferation. We found that the first-generation E1/E3-deleted adenovirus vectors differentially modulated lactotroph proliferation in a mitogen and infection timedependent manner. In addition, we measured the activities of mitogen signaling pathways in adenovirus-infected cells and correlated them with changes in cell proliferation.

\section{Materials and Methods}

\section{Plasmids and adenovirus vectors}

Adenovirus vectors were produced using the Adeno-X Expression and Adeno-X Tet-On Expression Systems according to the manufacturer's protocol (Clontech Laboratories). The adenovirus vector Ad- $\beta$ gal, which expresses $\beta$ gal under the control of the human cytomegalovirus immediate early gene (CMV) promoter, was purchased from Clontech Laboratories. Ad-Tet.On, an adenovirus expressing CMV-driven rTetRVP16, and Ad-TRE/Bgal, an adenovirus expressing $\beta$ gal in a tetracycline-regulated manner, have been described in detail previously (Ishida et al. 2007a). An adenovirus expressing firefly luciferase driven by the CMV promoter (Ad-luc) was produced by inserting luciferase cDNA of pGL3-Basic into the NheI/XbaI sites in the pShuttle vector. To produce an adenovirus carrying the rat prolactin (PRL) promoter but no cDNA for exogenous proteins (Ad-emp), a pGL3 vector containing a $3 \cdot 2-\mathrm{kb}$ fragment of the rat PRL promoter (Ishida et al. 2007b) was digested with HindIII and XbaI to delete luciferase cDNA and then cloned into the NotI/BamHI sites in pTRE-Shuttle2-NruI.MCS.SmaI (Ishida et al. 2007a). These modified pShuttle and pTREShuttle2 vectors were digested with I-CeuI and PI-SceI, and the genes of interest were inserted into a site created with the same restriction enzymes in Adeno-X viral DNA, a replicationdefective adenoviral genome. Adeno-X viral DNA was transfected into HEK293 cells using the FuGene 6 Transfection Reagent (Roche Diagnostics) for virus production, and the recombinant adenoviruses were further propagated by serial infection in HEK293 cells. The adenoviruses obtained were purified with the Adeno-X virus purification kit (Clontech Laboratories) and concentrated with the Centricon Centrifugal Filter Unit (Millipore, Bedford, MA, USA). Adenovirus vector titers (infectious units, ifu) were determined using the Adeno-X Rapid Titer Kit (Clontech Laboratories).

\section{Cell culture and viral infection}

Experiments were approved by the Ethical Committee of Animal Experiments of the University of Yamanashi. Sevenweek-old female Wistar rats, purchased from Japan SLC (Shizuoka, Japan), were used to obtain anterior pituitary cells for the primary culture. Anterior pituitary cells were dispersed as described previously (Kawashima et al. 2002). A $100 \mu$ aliquot of a cell suspension containing $2 \cdot 0 \times 10^{5}$ pituitary cells was combined with the adenovirus vectors at appropriate MOIs in a 1:1 mixture of Dulbecco's modified Eagle's medium (DMEM) and Ham's Nutrient Mix F-12 without phenol red, containing $15 \mathrm{mM}$ HEPES, penicillin, and streptomycin (DMEM/F12). The cells were then plated in poly-D-lysine-coated $35 \mathrm{~mm}$ culture dishes. The cells were then subsequently allowed to attach to the surface of the dishes in a humidified $\mathrm{CO}_{2}$ incubator for $1 \mathrm{~h}$. The pituitary cells were then flooded with $2 \mathrm{ml}$ DMEM/F12 containing $500 \mathrm{ng} / \mathrm{ml}$ insulin and precultured at $37^{\circ} \mathrm{C}$ in a humidified atmosphere of $5 \% \mathrm{CO}_{2}$ and $95 \%$ air for 1 day. After 1 day of preculture, the pituitary cells were washed with DMEM/F12 to remove adenoviruses and cultures were initiated with a serum-free, chemically defined medium (Kawashima et al. 2002). In experiments using Ad-TRE/Bgal and Ad-Tet.On, doxycycline was added at a concentration of $10 \mu \mathrm{g} / \mathrm{ml}$ to induce the reverse Tet repressor protein and thereby $\beta$ gal protein. Cultured pituitary cells were treated with the following mitogens: forskolin $(1 \mu \mathrm{M})$, insulin-like growth factor-I (IGF-I; $30 \mathrm{ng} / \mathrm{ml})$, bromocriptine $(10 \mathrm{nM}), 17 \beta-$ estradiol $\left(\mathrm{E}_{2} ; 1 \mathrm{nM}\right)$, fetal bovine serum (FBS; $\left.5 \%\right)$, and dextran-coated charcoal-striped (DCC) horse serum (10\%). For labeling proliferating pituitary cells, the cultured cells were treated with $200 \mu \mathrm{M}$ 5-bromo- $2^{\prime}$-deoxyuridine (BrdU) for $3 \mathrm{~h}$ prior to the end of culture.

\section{Immunostaining}

To determine the BrdU-labeling index, pituitary cells labeled with BrdU were detached from culture dishes at the end of culture by trypsin treatment. The cells were attached to polyD-lysine-coated glass slides by centrifugation using a cytocentrifuge and fixed with ice-cold methanol. The pituitary cells, attached to glass slides, were double immunostained for BrdU and PRL as described previously (Kawashima et al. 2002). Immunostained slides were covered with PermaFluor (Immunon, Pittsburgh, PA, USA) and examined using a fluorescence microscope equipped with a dual-band mirror unit for fluorescein isothiocyanate (FITC) and Texas Red. A total of 1000 PRL-immunoreactive cells were examined in randomly chosen fields for each slide to determine the BrdU-labeling index, which was the percentage of cells immunoreactive for both PRL and BrdU of the total PRL-immunoreactive cells counted.

For double immunostaining for phosphorylated cAMP response element-binding protein (pCREB) and PRL, the pituitary cells cultured on dishes were fixed with paraformaldehyde, permeabilized with TBS containing 1\% Tween 20 
and treated with 3\% hydrogen peroxide. After blocking nonspecific binding by using a blocking reagent supplied in the tyramide signal amplification (TSA) fluorescence system (Perkin-Elmer, Boston, MA, USA), the pituitary cells were immunostained for $\mathrm{pCREB}$ and PRL as described previously (Ishida et al. 2007a). Fluorescence images of pCREB and PRL labeled with FITC-tyramide and AlexaFluor 594 respectively were captured with a digital CCD camera and stored in a personal computer. The pCREB immunoreactivity was quantified by measuring the fluorescence intensity of nuclear FITC with Photoshop imaging software (Adobe Systems), and a cell with a fluorescence intensity higher than a level of 60-85 was defined as a pCREB-immunoreactive cell. The pituitary cells immunoreactive for both $\mathrm{pCREB}$ and PRL were counted in a total of 200 PRL-immunoreactive cells.

\section{Bgal histochemistry}

Pituitary cells cultured on dishes were fixed with $3 \%$ paraformaldehyde in $0 \cdot 1 \mathrm{M}$ phosphate buffer for $10 \mathrm{~min}$ and rinsed with TBS containing $0 \cdot 1 \%$ Tween 20 (TBST). The pituitary cells were permeabilized with TBS containing 1\% Tween 20 for $30 \mathrm{~min}$ and incubated with PBS containing $5 \mathrm{mM} \mathrm{K}_{4} \mathrm{Fe}(\mathrm{CN})_{6}, 5 \mathrm{mM} \mathrm{K}_{3} \mathrm{Fe}(\mathrm{CN})_{6}, 2 \mathrm{mM} \mathrm{MgCl}_{2}$, and $1 \mathrm{mg} / \mathrm{ml} \mathrm{X}$-gal at $37^{\circ} \mathrm{C}$ for $1 \mathrm{~h}$.

\section{Immunoblotting}

The pituitary cells, cultured at a cell number of $9 \times 10^{5}$ cells/35 mm dish, were lysed with $100 \mu \mathrm{l}$ ice-cold lysis buffer composed of $20 \mathrm{mM}$ Tris, $\mathrm{pH} 7 \cdot 6,137 \mathrm{mM} \mathrm{NaCl}, 1 \%$ Nonidet P-40, 0.5\% sodium deoxycholate, $0 \cdot 1 \%$ SDS, $2 \mathrm{mM}$ phenylmethylsulfonyl fluoride, $1 \mathrm{mM}$ sodium orthovanadate, and protease inhibitor cocktail (aprotinin, bestatin, leupeptin, and pepstatin A) (sc-24948, Santa Cruz Biotechnology, Santa Cruz, CA, USA) for $15 \mathrm{~min}$ at $4{ }^{\circ} \mathrm{C}$. The cell lysates were placed on ice for $30 \mathrm{~min}$ in microcentrifuge tubes and vortexed every $10 \mathrm{~min}$, and whole-cell extract of soluble protein was obtained by centrifugation at $17500 \mathrm{~g}$ for $15 \mathrm{~min}$ at $4{ }^{\circ} \mathrm{C}$. The protein concentration of the supernatants was determined using the BCA Protein Assay Kit (Pierce Biotechnology, Rockford, IL, USA). The supernatant aliquots containing equal amounts of total protein $(5-20 \mu \mathrm{g})$ were denatured in $2 \times$ sample buffer composed of $125 \mathrm{mM}$ Tris, pH 6.8, 4\% SDS, 10\% glycerol, 5\% $\beta$-mercaptoethanol, and $0 \cdot 2 \%$ bromophenol blue for $5 \mathrm{~min}$ at $99{ }^{\circ} \mathrm{C}$ and electrophoresed on a $12 \cdot 5 \%$ SDS-polyacrylamide gel. Separated proteins were transferred to the polyvinylidene difluoride membrane (Hybond-P; Amersham Biosciences). The membrane was blocked for $1 \mathrm{~h}$ with $5 \%$ nonfat dry milk in TBST and then incubated with primary antibodies in TBST containing $5 \%$ BSA at $4{ }^{\circ} \mathrm{C}$ overnight. The primary antibodies were labeled for $1 \mathrm{~h}$ with a horseradish peroxidase-conjugated anti-rabbit or mouse IgG antibody (Amersham Biosciences; 1:10 000 dilution in TBST). The membrane was reacted with the reagent included with the ECL plus western blotting detection system (Amersham Biosciences) according to the manufacturer's instructions, and the signal was detected with a luminoimage analyzer (LAS-1000 plus, Fuji Photo Film, Tokyo, Japan). The primary antibodies used were as follows: anti-cyclin D1 (SC-6281; 1:300 dilution) purchased from Santa Cruz Biotechnology, anti-pCREB (Ser133) (\#9198) (1:500 dilution), anti-phosphorylated p44/42 MAPK (Thr202/Tyr204) (\#9101) (1:2000 dilution), anti-AKT (\#9272) (1:2000 dilution), and antiphosphorylated AKT (Ser473) (\#9271) (1:500 dilution) from Cell Signaling Technology (Beverly, MA, USA), anti-ERK1 (\#610030) (1:4000 dilution) from Becton Dickinson Biosciences (Bedford, MA), anti-CREB (\#238461) (1:1000 dilution) from Calbiochem-EMD Chemicals (Darmstadt, Germany), and anti$\beta$-actin (A-5441) (1:10 000 dilution) from Sigma.

\section{Quantitative real-time PCR ( $q R T-P C R)$}

Expression levels of $\mathrm{mRNAs}$ for estrogen-responsive genes were determined by qRT-PCR as described previously (Ishida et al. 2007a). Total pituitary RNA was isolated using the RNeasy Mini Kit (Qiagen) and treated with RNase-free DNase I (Qiagen). RNA was reverse transcribed using an oligo (dT)20 primer and ReverTra Ace reverse transcriptase (Toyobo, Osaka, Japan). Reverse transcriptase reactions were amplified on an ABI Prism 7500 Sequence Detection System (Applied Biosystems, Foster City, CA, USA) using the SYBR Green Real-Time PCR Kit (Toyobo). The primers used are shown in Table 1. The mRNA levels were calculated by the $2^{-\Delta \Delta C_{\mathrm{T}}}$ method using acid ribosomal phosphoprotein $\mathrm{PO}(A r b p)$ as an endogenous reference. The fold change in gene expression of the estradiol treated group was determined relative to the vehicle-treated control in each experiment, and the mean of the fold changes obtained from three independent experiments was then calculated.

\section{Statistical analysis}

Experiments were replicated at least three times with separate batches of cell preparations. Differences between groups were

Table 1 The primers used for quantitative real-time PCR to determine mRNA levels of estrogen-responsive genes

Sequence $\left(5^{\prime} \rightarrow 3^{\prime}\right)$

\begin{tabular}{|c|c|c|}
\hline \multicolumn{3}{|l|}{ Primer } \\
\hline \multirow[t]{2}{*}{ Pim3 } & Forward & GGACAGAGTCTCAAGCCCTTAATT \\
\hline & Reverse & САСТTTTGAАСТTATACAАССССАСС \\
\hline \multirow[t]{2}{*}{ Plag/1 } & Forward & CTGACTGGGACACTCATGATTCTC \\
\hline & Reverse & AGTAGGTTAAGCTAGGAAAGAAAATTC \\
\hline \multirow[t]{2}{*}{ Stat5a } & Forward & TTCTGCСAGAAGСTCСTTGTC \\
\hline & Reverse & GGTGCAAAGCCACTGGTATGA \\
\hline \multirow[t]{2}{*}{ Serpine1 } & Forward & GTGTGACCTAACAGGACAGAACTTTC \\
\hline & Reverse & CACGTGTCCACTGCTCACTTACA \\
\hline \multirow[t]{2}{*}{$c-m y c$} & Forward & ATGCATGCTCAAAGCСТAACCT \\
\hline & Reverse & GGCAGTTAACATTATGGCTGAAGTC \\
\hline \multirow[t]{2}{*}{ Arbp } & Forward & GCСТСАСТССАТСАТСAATGG \\
\hline & Reverse & TTTTCAGCCAGTGGGAAGGT \\
\hline
\end{tabular}

Journal of Endocrinology (2008) 198, 209-217 
statistically analyzed using the one-way ANOVA followed by Fisher's protected least significant difference test.

\section{Results}

Adenovirus vectors differentially modulate mitogen-induced proliferation of lactotrophs

The ability of adenoviruses to express exogenous protein was verified in the primary cultures of the anterior pituitary cells using $\beta$ gal histochemistry. After a 3-day infection at an MOI of 5 with Ad- $\beta$ gal, an adenovirus vector encoding the $\beta$ gal gene downstream of the CMV promoter, many cells exhibited $\beta$ gal activity (Fig. $1 \mathrm{~A}$ and B). The $\beta$ gal activity was also seen when cells were co-infected with Ad-Tet.On and Ad-TRE/ $\beta$ gal, an adenovirus encoding the $\beta$ gal gene downstream of the tetracycline-responsive expression cassette and treated with the tetracycline analog doxycycline (Fig. 1C).

To determine the effects of adenovirus vector infection on lactotroph proliferation, pituitary cells were infected with no virus, Ad- $\beta$ gal ( $5 \mathrm{MOIs}$ ), or a combination of Ad-TRE/ $\beta \mathrm{gal}$ and Ad-Tet.On (Ad-TRE/ $\beta$ gal + Ad-Tet.On) (2.5 MOIs each). The MOIs were chosen based on our previous study (Ishida et al. 2007a). The cells were then treated with various mitogens known to act on lactotrophs and labeled with BrdU to detect proliferating cells. Infection with Ad- $\beta$ gal or Ad-TRE/ $\beta$ gal + Ad-Tet.On significantly raised basal levels of lactotroph proliferation in vehicle-treated cells $(P<0 \cdot 05)$, an effect that was consistently observed in many experiments shown in Figs 2 and 3. The magnitude of the increase in basal proliferation was always greater in Ad-TRE/ $\beta$ gal + AdTet.On-infected cells than in Ad- $\beta$ gal-infected cells. Treatment for $24 \mathrm{~h}$ with forskolin, an adenylate cyclase activator, and IGF-I significantly increased lactotroph proliferation in adenovirus-uninfected cells $(P<0 \cdot 05)$. The degree of increase was similar in Ad- $\beta$ gal- or Ad-TRE/ $\beta$ gal + Ad-Tet.Oninfected cells (Fig. 2A and B). Dopamine secreted by hypothalamic neurons inhibits a variety of lactotroph functions

A
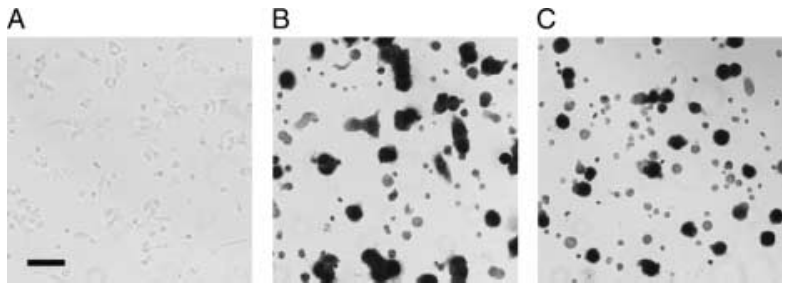

Figure $1 \mathrm{Bgal}$ protein expression by infection of pituitary cells with Ad- $\beta$ gal or a combination of Ad-TRE/ $\beta$ gal and Ad-Tet.On (Ad-TRE/Bgal+Ad-Tet.On). Primary cultures of pituitary cells were (A) uninfected or (B) infected with Ad-Bgal at 5 MOls or (C) Ad-TRE/Bgal + Ad-Tet.On at 2.5 MOls each. The cells infected with Ad-TRE/Bgal and Ad-Tet.On were treated with $10 \mu \mathrm{g} / \mathrm{ml}$ doxycycline. After a 3-day infection, the cells were fixed with paraformaldehyde and subjected to $\beta$ gal histochemistry. Scale bar, $30 \mu \mathrm{m}$.
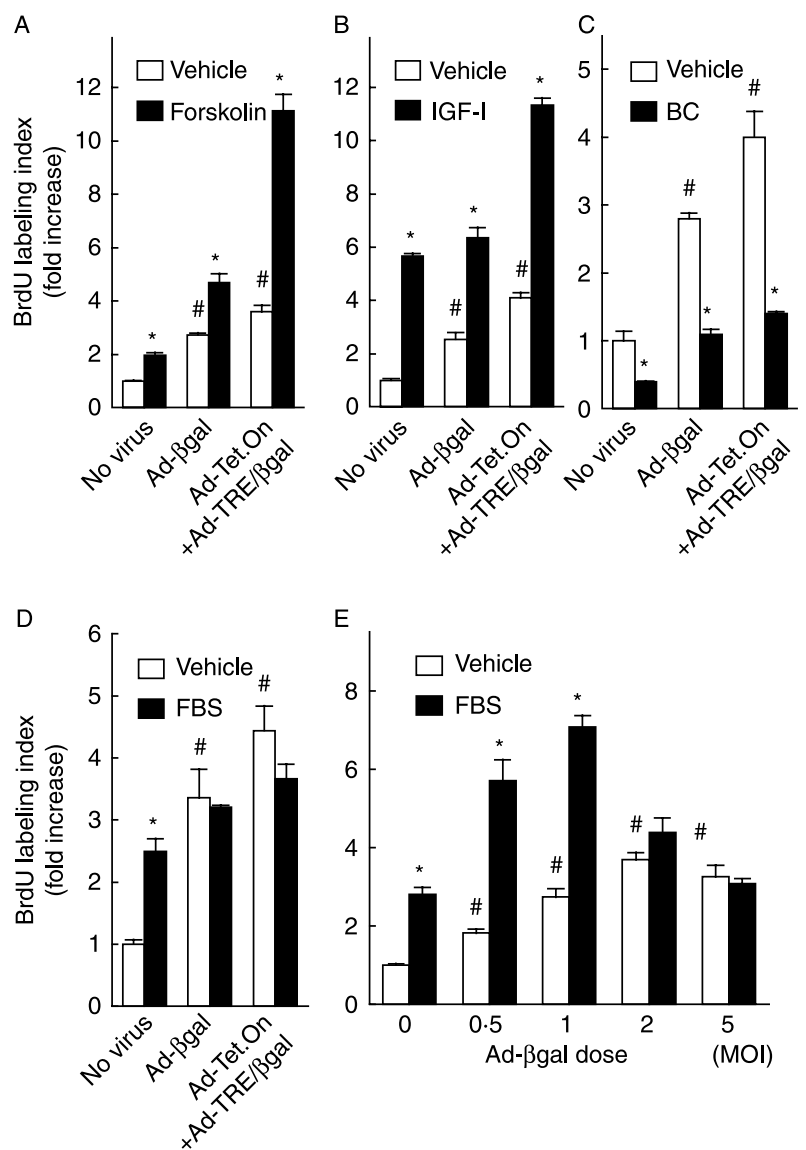

Figure 2 Effects of infection with Ad- $\beta$ gal or Ad-TRE/ $\beta g a l+A d-$ Tet.On on the proliferation of lactotrophs in primary culture in response to a variety of mitogens. The primary cultures of pituitary cells were uninfected or infected with Ad- $\beta$ gal at 5 MOls or Ad-TRE/Bgal+Ad-Tet.On at 2.5 MOls each, in which $10 \mu \mathrm{g} / \mathrm{ml}$ doxycycline was given. These cells were challenged 2 days later by 24-h treatment with vehicle, (A) $1 \mu \mathrm{M}$ forskolin, (B) $30 \mathrm{ng} / \mathrm{ml} \mathrm{IGF-I,}$ (C) $10 \mathrm{nM}$ bromocriptine (BC), or (D) $5 \%$ fetal bovine serum (FBS). (E) The MOl of Ad- $\beta$ gal infection ranged from 0 to 5, and cells were treated with FBS. BrdU labeling indexes for lactotrophs determined by double immunostaining for PRL and BrdU are expressed as a fold increase relative to the uninfected, vehicle-treated group. Data are means \pm S.E.M. of triplicate determinations from a representative experiment. *Significantly different from the corresponding vehicletreated groups at $P<0 \cdot 05$; \#significantly different from the uninfected, vehicle-treated group at $P<0 \cdot 05$.

in vivo and in vitro (Ben-Jonathan \& Hnasko 2001). Treatment with bromocriptine, a dopaminergic agonist, significantly decreased lactotroph proliferation in adenovirus-uninfected cells $(P<0 \cdot 05)$. Similar decreases were also seen in the adenovirus-infected cells (Fig. 2C). However, the stimulatory action of FBS on lactotroph proliferation, normally seen in adenovirus-uninfected cells, was completely lost in Ad- $\beta$ galor Ad-TRE/ $\beta$ gal + Ad-Tet.On-infected cells $(P>0 \cdot 05)$ (Fig. 2D). Dose-response studies revealed that the action of FBS on proliferation was blocked by Ad- $\beta$ gal infection at MOIs of more than 2 (Fig. 2E). 

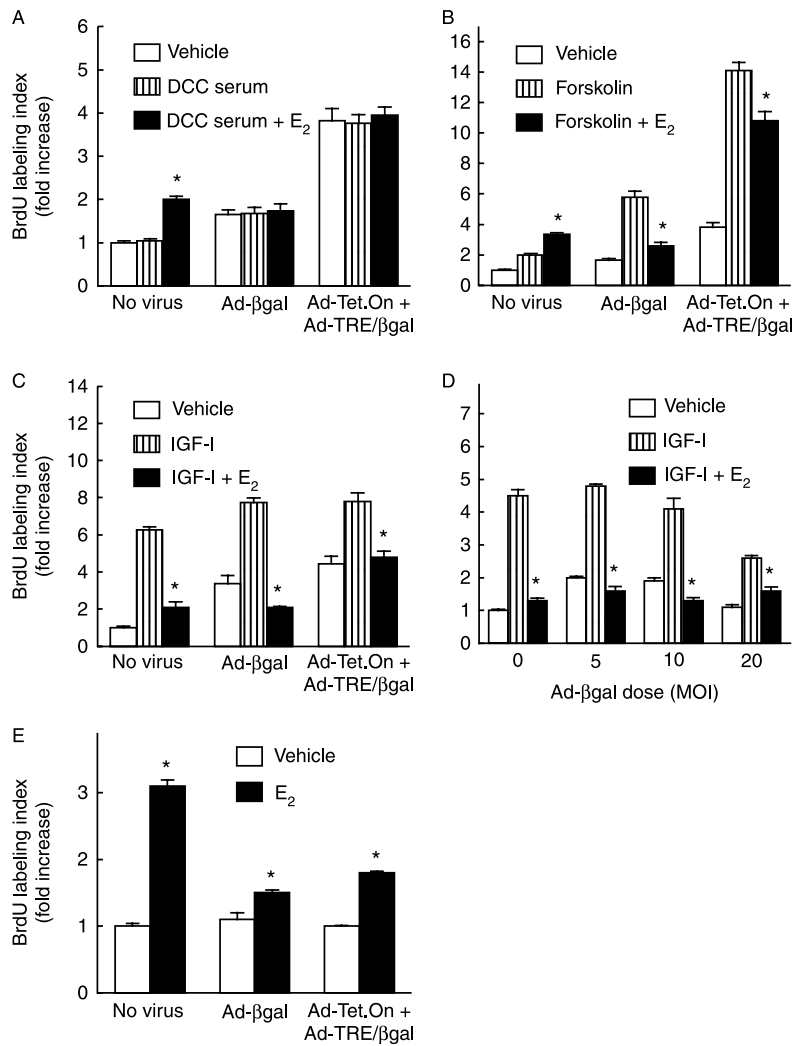

Figure 3 Effects of infection with Ad- $\beta$ gal or Ad-TRE/ $\beta g a l+A d-T e t . O n$ on the stimulatory and inhibitory actions of $E_{2}$ on lactotroph proliferation. The pituitary cells were infected with Ad- $\beta$ gal or Ad-TRE/Bgal+Ad-Tet.On as described in detail in Fig. 2. (A) These cells were challenged by $24-\mathrm{h}$ treatment with vehicle, $10 \%$ dextrancoated charcoal-treated (DCC) serum alone or in combination with $1 \mathrm{nM} 17 \beta$-estradiol $\left(\mathrm{E}_{2}\right)$, (B) forskolin alone or in combination with $\mathrm{E}_{2}$, or (C) IGF-I alone or in combination with $\mathrm{E}_{2}$, or (E) 96-h treatment with vehicle or $\mathrm{E}_{2}$ alone. (D) The $\mathrm{MOI}$ of $\mathrm{Ad}-\beta$ gal infection ranged from 0 to 20 , and cells were treated with IGF-I alone or in combination with $E_{2}$. The BrdU labeling indexes for lactotrophs are expressed as a fold increase relative to the uninfected, vehicle-treated group. Data are means \pm S.E.M. of triplicate determinations from a representative experiment. *Significantly different from the corresponding mitogen alone-treated groups.

We have previously shown that estrogen exerts opposing actions on the proliferation of lactotrophs in the primary culture depending upon the mitogen context. Treatment with $\mathrm{E}_{2}$ alone or in combination with DCC serum or forskolin stimulates proliferation, while $\mathrm{E}_{2}$ inhibits proliferation in combination with insulin or IGF-I (Kawashima et al. 2002). Therefore, we tested whether adenovirus infection modulates the stimulatory and inhibitory actions of $\mathrm{E}_{2}$ on lactotroph proliferation. Unlike FBS, DCC serum alone did not alter basal proliferation in either adenovirus-uninfected or infected cells; and $E_{2}$ administered simultaneously with DCC serum for $24 \mathrm{~h}$ significantly increased proliferation in adenovirus-uninfected cells $(P<0 \cdot 05$; Fig. $3 \mathrm{~A})$. However, $E_{2}$ failed to increase proliferation in the presence of DCC serum in Ad- $\beta$ gal- or Ad-TRE/ $\beta$ gal + Ad-Tet.On- infected cells $(P<0 \cdot 05)$. Forskolin-increased proliferation was further stimulated by simultaneous treatment with $E_{2}$ in adenovirus-uninfected cells $(P<0 \cdot 05$; Fig. 3B). Interestingly, infection with Ad- $\beta$ gal or Ad-TRE/ $\beta$ gal + Ad-Tet.On not only blocked the stimulatory action of $\mathrm{E}_{2}$ in the presence of forskolin but also reversed the action of $\mathrm{E}_{2}$ from stimulatory to inhibitory $(P<0 \cdot 05)$. By contrast, treatment with $\mathrm{E}_{2}$ inhibited IGF-I-induced proliferation in adenovirus-uninfected cells; and this action of $E_{2}$ remained unchanged in Ad- $\beta$ gal- or Ad-TRE/ $\beta$ gal + Ad-Tet.On-infected cells $(P<0 \cdot 05$; Fig. 3C). The inhibitory action of $E_{2}$ in the presence of IGF-I persisted even when the MOI of Ad- $\beta$ gal infection was increased up to 20 MOIs $\left(P<0 \cdot 05\right.$; Fig. 3D). $\mathrm{E}_{2}$ alone increases lactotroph proliferation, even in the absence of DCC serum or forskolin, but requires a longer treatment time of $96 \mathrm{~h}$ (Kawashima et al. 2002). The stimulatory action of $E_{2}$ alone was observed in adenovirus-uninfected cells $(P<0 \cdot 05$; Fig. 3E), but was attenuated following infection with Ad- $\beta$ gal or Ad-TRE/ ßgal+ Ad-Tet.On.

Adenovirus vector modulation of lactotroph proliferation via viral proteins and nonspecific transgene proteins

To examine whether the changes in lactotroph proliferation caused by Ad- $\beta$ gal and Ad-TRE/ $\beta$ gal + Ad-Tet.On were due to either a specific effect of $\beta$ gal, a common effect of expressed exogenous proteins, or an effect of adenovirus-derived proteins, we measured lactotroph proliferation in cells infected with Ad-luc, an adenovirus carrying the luciferase gene instead of the $\beta$ gal gene, and Ad-emp, an adenovirus expressing no exogenous protein. An increase in basal proliferation as observed in Ad- $\beta$ gal or Ad-TRE/ $\beta$ gal + Ad-Tet.On-infected cells was also seen in Ad-luc- or Ad-emp-infected cells $(P<0 \cdot 05$; Fig. 4A). Like Ad$\beta$ gal and Ad-TRE/ $\beta$ gal + Ad-Tet.On, both Ad-luc and Ad-emp blocked the stimulatory action of $\mathrm{E}_{2}$ in the presence of DCC serum or forskolin $(P<0 \cdot 05)$ (Fig. 4A and B).
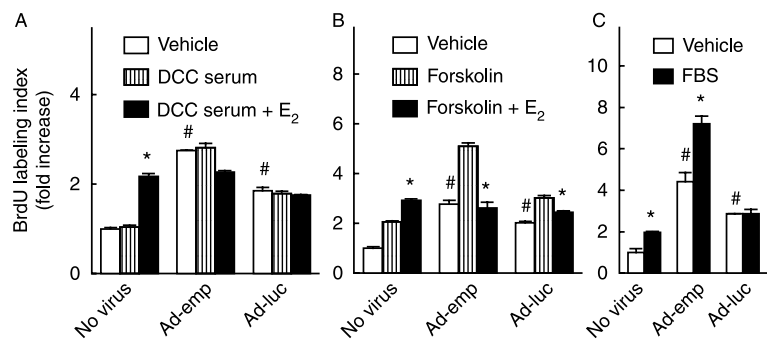

Figure 4 Effects of infection with Ad-emp or Ad-luc on lactotroph proliferation. The pituitary cells were uninfected or infected with Ad-emp or Ad-luc at $5 \mathrm{MOls}$ and challenged by 24-h treatment with vehicle, (A) DCC serum alone or in combination with $E_{2}$, (B) forskolin alone or in combination with $\mathrm{E}_{2}$, or (C) FBS. The BrdU labeling indexes for lactotrophs are expressed as a fold increase relative to the uninfected, vehicle-treated group. Data are means \pm S.E.M. of triplicate determinations from a representative experiment. *Significantly different from the corresponding mitogen alonetreated groups in (A and B) or vehicle-treated groups in $(\mathrm{C})$; \#significantly different from the uninfected, vehicle-treated group. 
However, FBS-induced proliferation was lost in Ad-lucinfected cells $(P<0 \cdot 05)$ but not in Ad-emp-infected cells (Fig. 4C).

\section{Infection time-dependent adenovirus vector modulation of lactotroph proliferation}

In the above-mentioned experiments, adenoviruses were infected for 3 days to determine their effect on lactotroph proliferation. We next asked whether the modulation of proliferation by adenovirus infection was a function of infection time. Time-course studies revealed that the increase in basal proliferation by Ad- $\beta$ gal or Ad-TRE/ $\beta$ gal + Ad-Tet.On peaked at 3 days after infection and was lost at 5 days, indicating a transient effect on basal proliferation (Fig. 5A). In addition, the blockade of FBS-induced proliferation by these adenoviruses observed at 3 days after infection was also lost at 5 days (Fig. 5B). FBS induced a dramatic proliferative effect in adenovirusinfected cells at this time point $(P<0 \cdot 05)$. By contrast, the blockade of the stimulatory action of $E_{2}$ in the presence of forskolin by Ad- $\beta$ gal or Ad-TRE/ $\beta$ gal + Ad-Tet.On persisted even at 5 days after infection $(P<0 \cdot 05$; Fig. $5 \mathrm{C})$.

\section{Adenovirus infection-induced changes in the activities of mitogenic signaling pathways}

We next determined whether the increased basal proliferation of lactotrophs caused by adenovirus infection was accompanied by changes in the activities of mitogenic signaling pathways in Ad- $\beta$ gal- and Ad-emp-infected cells. The western blot analysis revealed that expression levels of cyclin D1 protein were increased in these adenovirus-infected cells (Fig. 6A), consistent with the results on proliferation as determined by BrdU labeling. Phosphorylated forms of CREB and ERK1/2

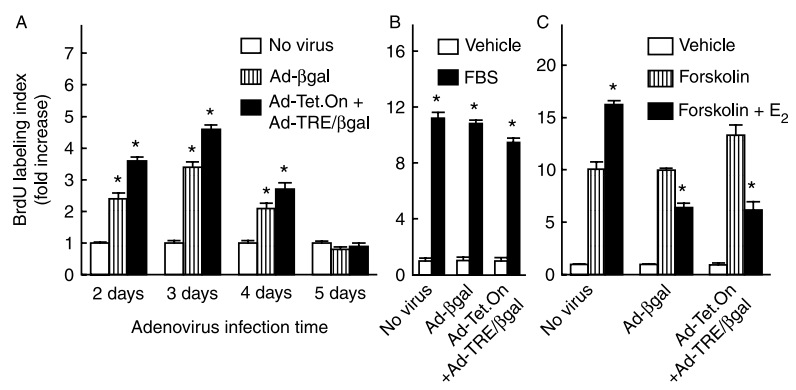

Figure 5 Time-course analysis of the effects of adenovirus infection on lactotroph proliferation. The pituitary cells were uninfected or infected with Ad- $\beta$ gal or Ad-TRE/Bgal +Ad-Tet.On for 2-5 days (3-day infection corresponds to the infection time of the groups in Figs 2-4) (A) without treatment or for 5 days followed (B) by a last 24-h treatment with FBS or $(C)$ forskolin alone or in combination with $E_{2}$. The BrdU labeling indexes for lactotrophs are expressed as a fold increase relative to the corresponding uninfected in $(A)$ or vehicle-treated groups in (B and C). Data are means \pm s.E.M. of triplicate determinations from a representative experiment. *Significantly different from the corresponding uninfected in (A), vehicletreated in $(B)$ or forskolin alone-treated groups in $(C)$.
A

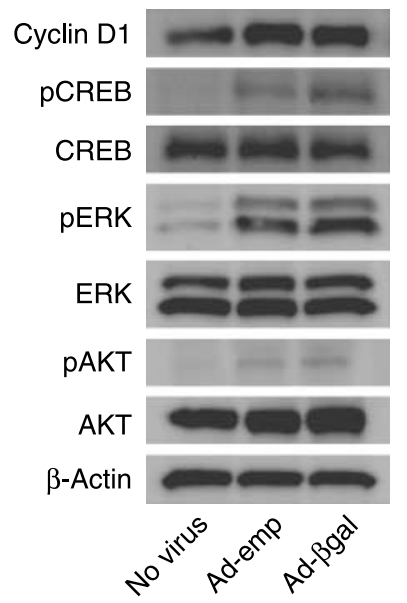

B

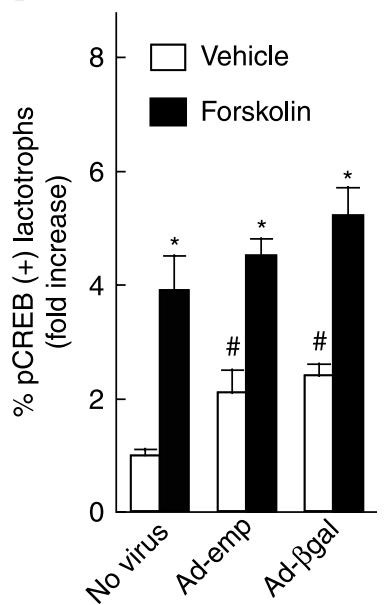

Figure 6 Changes in the activities of mitogenic signaling pathways in adenovirus vector-infected cells. (A) Pituitary cells were uninfected or infected with Ad-emp or Ad- $\beta$ gal at 5 MOls. After 3 days, cell lysates were collected for the western blot analysis to determine basal levels of cyclin D1 protein and the phosphorylated forms of CREB, ERK1/2, and AKT. $\beta$-Actin served as a loading control. (B) After 3 days of infection, cells were treated with either vehicle or $1 \mu \mathrm{M}$ forskolin for $3 \mathrm{~h}$, fixed with paraformaldehyde, and double-immunostained for PRL and phosphorylated CREB (pCREB). The percentage of pCREB-immunoreactive lactotrophs is expressed as a fold increase relative to the uninfected, vehicle-treated group. Data are means \pm S.E.M. of triplicate determinations from a representative experiment. *Significantly different from the corresponding vehicle-treated groups at $P<0 \cdot 05$; \#significantly different from the uninfected, vehicle-treated group at $P<0 \cdot 05$.

also showed an increase in Ad- $\beta$ gal or Ad-emp-infected cells compared with uninfected cells while CREB and ERK1 were not changed in either group. There was a modest increase in the expression level of phosphorylated AKT. Because it was possible that the change in PCREB in cell lysates from total pituitary cell populations as determined by western blotting did not necessarily correctly reflect a change in lactotrophs, we determined lactotroph-specific CREB activation in adenovirus-infected cells using quantitative double immunostaining for pCREB and PRL (Ishida et al. 2007a). The percentage of pCREB-immunoreactive lactotrophs was markedly increased by forskolin as a positive control in uninfected cells $(P<0 \cdot 05$; Fig. 6B). Infection with Ad- $\beta$ gal or Ad-emp significantly increased the percentage of $\mathrm{pCREB}$-immunoreactive lactotrophs in vehicle-treated cells $(P<0 \cdot 05)$.

\section{Adenovirus infection-induced changes in the expression of estrogen-responsive genes}

The differential modulation by adenovirus vector infection of the stimulatory and inhibitory actions of estrogen on lactotroph proliferation may be accompanied by changes in the response of estrogen-responsive genes to estrogen. We therefore determined $E_{2}$-induced mRNA expression levels of estrogen-responsive 
genes in Ad- $\beta$ gal- and Ad-emp-infected cells. The estrogenresponsive genes were chosen on the basis of the results in preliminary studies and included the estrogen-upregulated genes Pim3, Stat5, and $c-m y c$ and the estrogen-downregulated genes Plagl1 and Serpine1. The $\mathrm{E}_{2}$ responsiveness in their mRNA expression levels were verified in uninfected cells (Fig. 7). $E_{2}$-induced fold changes in mRNA levels of Pim3 and Plagl1 were not altered by either Ad-emp or Ad- $\beta$ gal infection $(P>0 \cdot 05)$. Both adenovirus vectors markedly enhanced the $\mathrm{E}_{2}$ responsiveness of Stat 5 a mRNA $(P<0 \cdot 05)$ while they attenuated the responsiveness of Serpine1 and $c-m y c$ mRNAs $(P<0 \cdot 05)$.

\section{Discussion}

Adenovirus vectors have been successfully used to transfer a gene to endocrine cells, in particular those from the anterior pituitary in vitro and in vivo (Castro et al. 1997, Lee et al. 1999, 2001, Neill et al. 1999, Southgate et al. 2000, Smith-Arica et al. 2001). We used pituitary lactotrophs cultured in serum-free medium as a model and evaluated the undesirable effects of adenovirus vector infection at a low MOI of 5 on cell proliferation. This study demonstrates that infection of lactotrophs with adenovirus

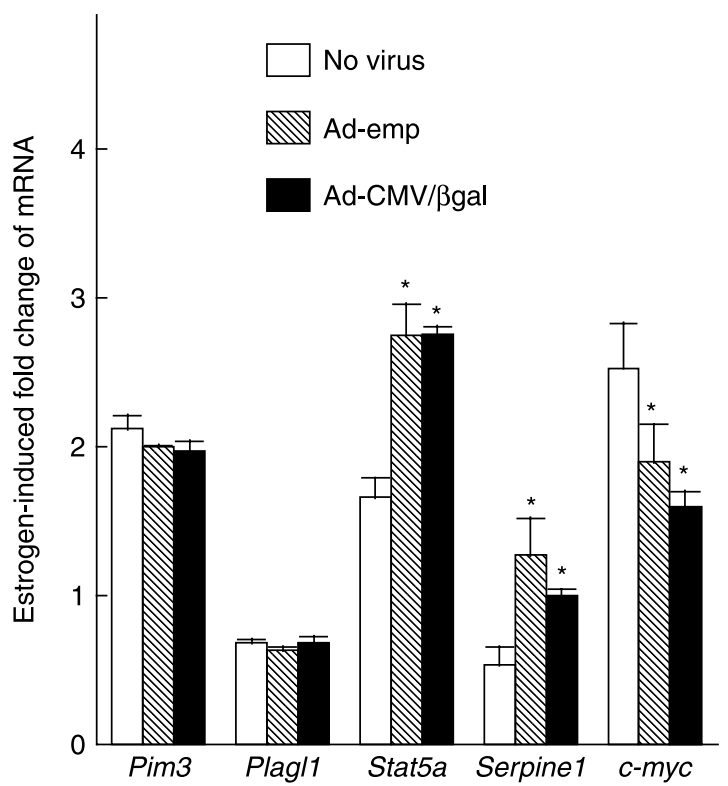

Figure 7 Differential effects of adenovirus vector infection on $E_{2^{-}}$ induced mRNA expressions of pituitary estrogen-responsive genes. The pituitary cells were uninfected or infected with Ad-emp or Ad$\beta$ gal at 5 MOls, and, 2 days later, were treated with vehicle or $1 \mathrm{nM}$ $\mathrm{E}_{2}$ for $4 \mathrm{~h}$. Total RNAs were collected for determination of mRNA levels of Pim3, Plag/1, Stat5a, Serpine1, and c-myc by means of quantitative real-time PCR. The mRNA levels of the genes were normalized to those of Arbp as an endogenous reference and responses to estrogen were expressed as a fold change in mRNA levels relative to the vehicle-treated group. Data are means \pm s.E.M. of triplicate experiments. *Significantly different from the corresponding uninfected groups at $P<0 \cdot 05$. vectors expressing $\beta$ gal markedly increases basal proliferation of lactotrophs. Since a similar increase in basal proliferation by adenovirus vectors is also observed in adrenocortical cells in the primary culture (Alesci et al. 2002), it is likely that adenovirus vectors generally stimulate basal proliferation in endocrine cells in the primary culture. In contrast to the stimulation of basal proliferation, the adenovirus vectors differentially inhibited mitogen-induced proliferation in a mitogen-dependent manner. The adenovirus vectors did not alter the actions offorskolin, IGF-I, and bromocriptine alone, and $\mathrm{E}_{2}$ in combination with IGF-I. They attenuated or blocked the actions of FBS and $\mathrm{E}_{2}$ alone, and $\mathrm{E}_{2}$ in combination with DCC serum. Interestingly, the stimulatory action of $\mathrm{E}_{2}$ in the presence of forskolin, normally observed in uninfected cells, was reversed to inhibition in adenovirus vector-infected cells. In addition, the modulation of lactotroph proliferation by the adenovirus vectors was infection-time dependent. The increased basal proliferation and the blockade of FBS action were transient and lost at 5 days after infection, while the blockade of the stimulatory action of $\mathrm{E}_{2}$ in combination with forskolin persisted at the same infection time. The results of modulation of lactotroph proliferation by adenovirus vector infection illustrate the importance of considering whether the mitogen used or the infection time is susceptible to adenovirus-mediated interference. For example, in lactotrophs in primary culture, adenovirus vectors can be used in studies using forskolin, IGF-I, and bromocriptine alone, and $\mathrm{E}_{2}$ in combination with IGF-I as mitogens without reservation. In order to apply adenovirus vectors in studies using FBS as a mitogen, FBS must be administered not earlier than 5 days after infection to avoid confounding of the results by the adenovirus.

It is possible that the modulation of lactotroph proliferation, observed in cells infected with adenovirus vectors expressing $\beta g a l$, is due to a specific effect of $\beta$ gal expression, a nonspecific effect of exogenous protein expression by the transferred gene, or an effect of adenovirus-derived proteins. We addressed this possibility by using Ad-luc and Ad-emp. Modulation of basal proliferation and proliferation stimulated by estrogen in combination with DCC serum or forskolin, as observed in $\beta$ gal-expressing adenovirus vector-infected cells, was also seen by infection with Ad-luc and Ad-emp. These results indicate that the viral proteins and not the transgene proteins are responsible for these changes. By contrast, the blockade of FBS-stimulated proliferation was seen following infection with Ad-luc but not with Ad-emp, indicating that the FBS action on lactotroph proliferation is blocked by the expression of an exogenous transgene protein. This study yielded three key observations. First, adenovirus infection modulates mitogeninduced proliferation in a mitogen-dependent manner. Secondly, adenovirus-mediated modulations are caused by both adenovirus-derived proteins and exogenous transgene proteins. Finally, a time course exists for modulation of mitogen activity following adenovirus infection, as exemplified by the difference in the persistence of the changes in basal and estrogenstimulated proliferation. These findings suggest that the adenovirus-mediated modulation of lactotroph proliferation involves a complicated, multi-factorial mechanism. 
The identities of the adenovirus-derived proteins that are responsible for the modulation of increased basal proliferation and estrogen-stimulated proliferation are currently undetermined. Adenoviruses have many genes that are capable of promoting transformation, cell proliferation, and transcriptional activity in infected cells (Leppard 1997). An E4 gene product, the E4-orf6/7 protein, may be responsible for the increased basal proliferation of lactotrophs. This is likely because the adenovirus vectors used in this study are human adenovirus serotype 5 with deletions of the early genes E1 and E3. Transcription of E2F-1, a member of the E2F transcription factor family that plays a pivotal role in the regulation of cell proliferation (Stevens \& La Thangue 2003 ) is positively regulated by E2Fs themselves (Hsiao et al. 1994, Johnson et al. 1994). Schaley et al. (2000) have shown that E4-orf6/7 interacts directly with a heterodimer consisting of E2F and the DP protein and induces the binding of E2F to the E2F-1 promoter in infected cells. This leads to stimulation of E2F-1 promoter activity and protein expression. Thus, E4-orf6/7 may stimulate basal proliferation of lactotrophs via E2F induction.

We observed that the increased basal proliferation of lactotrophs by Ad-emp or Ad- $\beta$ gal was accompanied by increased basal levels of phosphorylated CREB and ERK in pituitary cells. Additionally, the result of a greater proportion of pCREB-immunoreactive lactotrophs, demonstrated by double immunostaining for $\mathrm{pCREB}$ and PRL, verifies that pCREB is increased in lactotrophs. Furthermore, the elevated pCREB is not due to an increase in cell number resulting from increased basal proliferation, but to more pCREB per cell. Consistent with these findings, protein kinase A activity and CREB binding in human umbilical vein endothelial cells are stimulated by a $\beta$ gal-expressing adenovirus vector (Zhang et al. 2005). ERK is activated by adenovirus vectors in a kidney-derived epithelial cell line (Tibbles et al. 2002) and lung epithelial cells (Flaherty et al. 2004). Both the protein kinase A/CREB and ERK signaling pathways are implicated in the regulation of lactotroph proliferation (Suzuki et al. 1999, Fernández et al. 2003, Yamakawa \& Arita 2004, Chaturvedi \& Sarkar 2005, Ishida et al. 2007a). Thus, CREB and ERK activation are likely to be involved in the increased basal proliferation induced by adenovirus vectors, although it is unknown whether the relationship is parallel or causal.

Estrogen regulates both normal and cancer cell proliferation in estrogen-responsive tissues via estrogen receptor-mediated expression of genes that regulate cell proliferation (Weisz \& Bresciani 1993, Dickson \& Lippman 1995). We investigated whether the influence of adenovirus vectors on estrogen effects was mediated by a change in the response to estrogen of estrogen-responsive genes. We measured, in adenovirusinfected cells, $E_{2}$-induced expression levels of various estrogen-responsive pituitary cell genes that regulate proliferation (Hennighausen et al. 1997, Obaya et al. 1999, Deneen et al. 2003, Durand et al. 2004, Abdollahi 2007). The $\mathrm{E}_{2}$ responsiveness of $\mathrm{mRNA}$ levels of the estrogen-upregulated gene Pim 3 and the estrogen-downregulated gene Plagl1 was not altered by adenovirus vectors, the response of the upregulated gene $c-m y c$ and downregulated gene Serpine 1 was attenuated, and that of Stat $5 a$ was enhanced. These results are the first to demonstrate changes in expression of estrogenresponsive genes by adenovirus vector infection. In addition, they suggest that the differential response of the stimulatory and inhibitory actions of estrogen to adenovirus infection is caused by differences in the response to adenovirus vectors among the various estrogen-responsive genes.

Adenovirus vectors are a promising means for gene transfer in normal cells in the primary culture. Ideally, the viral vector by itself should not affect the function of the target cells. We have shown in this study that adenovirus vectors modulate proliferation of pituitary lactotrophs in the primary culture more extensively than was originally thought. The modulation is dependent both on the mitogen and the infection time. The effects result both from viral proteins and delivered gene products. Because interfering modulation by adenovirus vectors may confound the results of experiments using them, a complete understanding of the interactions between adenovirus vectors and target cells is critical to the successful application of adenovirus vectors as gene transfer tools.

\section{Declaration of Interest}

The authors declare that there is no conflict of interest that would prejudice the impartiality of this scientific work.

\section{Funding}

This work was supported by the Ministry of Education, Science, and Culture of Japan (grant-in-aid for Scientific Research 17590198, 19590224).

\section{Acknowledgements}

The authors are grateful to Dr A F Parlow and the NIDDK for providing anti-PRL antibody and Ms W Takahashi for her technical assistance.

\section{References}

Abdollahi A 2007 LOT1 (ZAC1/PLAGL1) and its family members: mechanisms and functions. Journal of Cellular Physiology 210 16-25.

Alesci S, Ramsey WJ, Bornstein SR, Chrousos GP, Hornsby PJ, Benvenga S, Trimarchi F \& Ehrhart-Bornstein M 2002 Adenoviral vectors can impair adrenocortical steroidogenesis: clinical implications for natural infections and gene therapy. PNAS 99 7484-7489.

Ben-Jonathan N \& Hnasko R 2001 Dopamine as a prolactin (PRL) inhibitor. Endocrine Reviews 22 724-763.

Castro MG, Goya RG, Sosa YE, Rowe J, Larregina A, Morelli A \& Löwenstein PR 1997 Expression of transgenes in normal and neoplastic anterior pituitary cells using recombinant adenoviruses: long term expression, cell cycle dependency, and effects on hormone secretion. Endocrinology 138 2184-2194.

Chaturvedi K \& Sarkar DK 2005 Mediation of basic fibroblast growth factorinduced lactotropic cell proliferation by Src-Ras-mitogen-activated protein kinase p44/42 signaling. Endocrinology 146 1948-1955.

www.endocrinology-journals.org 
Chirmule N, Hughes JV, Gao G, Raper SE \& Wilson JM 1998 Role of E4 in eliciting CD4 T-cell and B-cell responses to adenovirus vectors delivered to murine and nonhuman primate lungs. Journal of Virology 72 6138-6145.

Crystal RG, McElvaney NG, Rosenfeld MA, Chu C, Mastrangeli A, Hay JG, Brody SL, Jaffe HA, Eissa T \& Danel C 1994 Administration of an adenovirus containing the human CFTR cDNA to the respiratory tract of individuals with cystic fibrosis. Nature Genetics 8 42-51.

Dai Y, Schwarz EM, Gu D, Zhang W, Sarvetnick N \& Verma IM 1995 Cellular and humoral immune responses to adenoviral vectors containing factor IX gene: tolerization of factor IX and vector antigens allows for longterm expression. PNAS 92 1401-1405.

Deneen B, Welford SM, Ho T, Hernandez F, Kurland I \& Denny CT 2003 PIM3 proto-oncogene kinase is a common transcriptional target of divergent EWS/ETS oncoproteins. Molecular and Cellular Biology 23 3897-3908.

Dickson RB \& Lippman ME 1995 Growth factors in breast cancer. Endocrine Reviews 16 559-589.

Durand MK, Bodker JS, Christensen A, Dupont DM, Hansen M, Jensen JK, Kjelgaard S, Mathiasen L, Pedersen KE, Skeldal S et al. 2004 Plasminogen activator inhibitor-1 and tumour growth, invasion, and metastasis. Thrombosis and Haemostasis 91 438-449.

Fernández M, Sánchez-Franco F, Palacios N, Sánchez I, Villluendas G \& Cacicedo L 2003 Involvement of vasoactive intestinal peptide on insulinlike growth factor I-induced proliferation of rat pituitary lactotropes in primary culture: evidence for an autocrine and/or paracrine regulatory system. Neuroendocrinology 77 341-352.

Flaherty DM, Hinde SL, Monick MM, Powers LS, Bradford MA, Yarovinsky T \& Hunninghake GW 2004 Adenovirus vectors activate survival pathways in lung epithelial cells. American Journal of Physiology. Lung Cellular and Molecular Physiology 287 L393-L401.

Hennighausen L, Robinson GW, Wagner KU \& Liu X 1997 Developing a mammary gland is a stat affair. Journal of Mammary Gland Biology and Neoplasia 2 365-372.

Hsiao KM, McMahon SL \& Farnham PJ 1994 Multiple DNA elements are required for the growth regulation of the mouse $\mathrm{E} 2 \mathrm{~F} 1$ promoter. Genes and Development 8 1526-1537.

Ishida M, Mitsui T, Yamakawa K, Sugiyama N, Takahashi W, Shimura H, Endo T, Kobayashi T \& Arita J 2007a Involvement of cyclic adenosine 3', $5^{\prime}$-monophosphate response element-binding protein in the regulation of cell proliferation and the prolactin promoter of lactotrophs in primary culture. American Journal of Physiology. Endocrinology and Metabolism 293 E1529-E1537.

Ishida M, Takahashi W, Itoh S, Shimodaira S, Maeda S \& Arita J 2007 b Estrogen actions on lactotroph proliferation are independent of a paracrine interaction with other pituitary cell types: a study using lactotrophenriched cells. Endocrinology 148 3131-3139.

Johnson DG, Ohtani K \& Nevins JR 1994 Autoregulatory control of E2F1 expression in response to positive and negative regulators of cell cycle progression. Genes and Development 8 1514-1525.

Kawashima K, Yamakawa K, Takahashi W, Takizawa S, Yin P, Sugiyama N, Kanba S \& Arita J 2002 The estrogen-occupied estrogen receptor functions as a negative regulator to inhibit cell proliferation induced by insulin/IGF1: a cell context-specific antimitogenic action of estradiol on rat lactotrophs in culture. Endocrinology 143 2750-2758.

Lee EJ, Anderson LM, Thimmapaya B \& Jameson JL 1999 Targeted expression of toxic genes directed by pituitary hormone promoters: a potential strategy for adenovirus-mediated gene therapy of pituitary tumors. Journal of Clinical Endocrinology and Metabolism 84 786-794.

Lee EJ, Rachel W, Kotlar T \& Jameson JL 2001 Restoration of growth hormone-releasing hormone (GHRH) responsiveness in pituitary GH3 cells by adenovirus-directed expression of the human GHRH receptor. Endocrinology 142 414-420.

Leppard KN 1997 E4 gene function in adenovirus, adenovirus vector and adenoassociated virus infections. Journal of General Virology 78 2131-2138.

Lieber A, He CY \& Kay MA 1997a Adenoviral preterminal protein stabilizes mini-adenoviral genomes in vitro and in vivo. Nature Biotechnology 15 1383-1387.
Lieber A, He C, Meuse L, Schowalter D, Kirillova I, Winther B \& Kay MA $1997 b$ The role of Kupffer cell activation and viral gene expression in early liver toxicity after infusion of recombinant adenovirus vectors. Journal of Virology 71 8798-8807.

Neill JD, Musgrove LC, Duck LW \& Sellers JC 1999 High efficiency method for gene transfer in normal pituitary gonadotropes: adenoviral-mediated expression of $\mathrm{G}$ protein-coupled receptor kinase 2 suppresses luteinizing hormone secretion. Endocrinology 140 2562-2569.

Obaya AJ, Mateyak MK \& Sedivy JM 1999 Mysterious liaisons: the relationship between c-Myc and the cell cycle. Oncogene 18 2934-2941.

Ramalingam R, Rafii S, Worgall S, Brough DE \& Crystal R G 1999 E1(-)E4(+) adenoviral gene transfer vectors function as a 'pro-life' signal to promote survival of primary human endothelial cells. Blood 93 2936-2944.

Schaley J, O'Connor RJ, Taylor LJ, Bar-Sagi D \& Hearing P 2000 Induction of the cellular E2F-1 promoter by the adenovirus E4-6/7 protein. Journal of Virology 74 2084-2093.

Seth P 2000 Adenoviral vectors. Advances in Experimental Medicine and Biology $46513-22$.

Smith-Arica JR, Williams JC, Stone D, Smith J, Löwenstein PR \& Castro MG 2001 Switching on and off transgene expression within lactotrophic cells in the anterior pituitary gland in vivo. Endocrinology 142 2521-2532.

Southgate TD, Windeatt S, Smith-Arica J, Gerdes CA, Perone MJ, Morris I, Davis JRE, Klatzmann D, Löwenstein PR \& Castro MG 2000 Transcriptional targeting to anterior pituitary lactotrophic cells using recombinant adenovirus vectors in vitro and in vivo in normal and estrogen/sulpiride-induced hyperplastic anterior pituitaries. Endocrinology $1413493-3505$

Stevens C \& La Thangue NB 2003 E2F and cell cycle control: a double-edged sword. Archives of Biochemistry and Biophysics 412 157-169.

Suzuki S, Yamamoto I \& Arita J 1999 Mitogen-activated protein kinasedependent stimulation of proliferation of rat lactotrophs in culture by $3^{\prime}$, $5^{\prime}$-cyclic adenosine monophosphate. Endocrinology 140 2850-2858.

Tibbles LA, Spurrell JCL, Bowen GP, Liu Q, Lam M, Zaiss AK, Robbins SM, Hollenberg MD, Wickham TJ \& Muruve DA 2002 Activation of p38 and ERK signaling during adenovirus vector cell entry lead to expression of the C-X-C chemokine IP-10. Journal of Virology 76 1559-1568.

Weisz A \& Bresciani F 1993 Estrogen regulation of proto-oncogenes coding for nuclear proteins. Critical Reviews in Oncogenesis 4 361-388.

Yamakawa K \& Arita J 2004 Cross talk between the estrogen receptor-, protein kinase A-, and mitogen-activated protein kinase-mediated signaling pathways in the regulation of lactotroph proliferation in primary culture. Journal of Steroid Biochemistry and Molecular Biology 88 123-130.

Yang Y, Xiang Z, Ertl HCJ \& Wilson JM 1995 Upregulation of class I major histocompatibility complex antigens by interferon $\gamma$ is necessary for T-cellmediated elimination of recombinant adenovirus-infected hepatocytes in vivo. PNAS 92 7257-7261.

Yeh P \& Perricaudet M 1997 Advances in adenoviral vectors: from genetic engineering to their biology. FASEB Journal 11 615-623.

Zhang F, Cheng J, Hackett NR, Lam G, Shido K, Pergolizzi R, Jin DK, Crystal RG \& Rafii S 2004 Adenovirus E4 gene promotes selective endothelial cell survival and angiogenesis via activation of the vascular endothelial-cadherin/Akt signaling pathway. Journal of Biological Chemistry 279 11760-11766.

Zhang F, Cheng J, Lam G, Jin DK, Vincent L, Hackett NR, Wang S, Young LM, Hempstead B, Crystal RG et al. 2005 Adenovirus vector E4 gene regulates connexin 40 and 43 expression in endothelial cells via PKA and PI3K signal pathways. Circulation Research 96 950-957.
Received in final form 7 April 2008
Accepted 11 April 2008
Made available online as an Accepted Preprint 11 April 2008 